\title{
USE OF ACTIVE SUBSTANCE DEPENDING OF THE FORMULATION OF PLANT PROTECTION PRODUCTS APPLIED WITH AGRICULTURAL SPRAYERS. A CASE STUDY OF WINTER WHEAT IN POLAND
}

\author{
Ewa MATYJASZCZYK \\ Plant Protection Institute - National Research Institute, Poznań, POLAND \\ E-mail of corresponding author: E.Matyjaszczyk@iorpib.poznan.pl
}

Keywords: crop protection, plant protection products, active substance, dose

\begin{abstract}
The study into the use of an active substance per hectare was performed to examine the matches of plant protection products applied by agricultural sprayers, containing the same active substance but with a different formulation. The doses of fungicides and herbicides registered in Poland to protect winter wheat against two economically important pests were analyzed. On the basis of the results it is difficult to draw any definite conclusions regarding the influence of formulation on the dose of active substance used per hectare. In some cases, use of a different formulation may be connected with the different amount of an active substance used per hectare. However, the results strongly differed depending on the analyzed active substances. It seems that more cases should be examined to determine whether there are any discernible patterns.
\end{abstract}

\section{INTRODUCTION}

In agriculture and food production numerous studies regarding overall safety (Kazimierczak et al. 2016, Melski et al. 2011) and residues in crops (Szpyrka et al. 2017, Jankowska et al. 2016) are performed. The fertilization and other aspects of plant cultivation influence the crop (Bereś 2016, Pikuła and Rutkowska 2014, Hurej et al. 2017, Zarzyńska et al. 2017, Matyjaszczyk 2011), but the public is especially concerned by the pest management, particularly chemical pest control.

From chemical point of view pesticides (plant protection products) are usually mixtures of active substance(s) and other components (solvents, emulsifiers, safeners, synergetics, adjuvants etc), introduced on the market in different formulations. The component of plant protection product that acts against the pest is the active substance. The aim of the other components is, generally speaking, enabling the safe and effective use of the active substance. From the point of view of environmental safety however it is not only the content of the active substance, but also the formulation and the form of application that counts (Doruchowski et al. 2017, Hoesel et al. 2017, Parafiniuk et al. 2015). Integrated pest management (IPM) - obligatory in all European Union member states from the beginning of 2014 emphasises the growth of a healthy crop with the least possible disruption to agro-ecosystems. The professional user should keep the use of pesticides and other forms of intervention to levels that are necessary; among others by reduced doses, reduced application frequency or partial applications (Directive 128/2009).

The aim of this paper is to answer the following question: If and how does the formulation of plant protection products affect the dose of active substance used per hectare?

\section{MATERIAL AND METHODS}

Research into the Polish register of plant protection products in May 2017 was carried out. The study was performed using fungicides and herbicides registered for the protection of winter wheat (the most important Polish crop as regards the cultivation area) against the same pests. The selected pests were powdery mildew (Blumeria 
graminis) in case of fungicides and lamb's quarters (Chenopodium album) in case of herbicides. The both pests are economically important in winter wheat production in Poland. All products on the market were analyzed. Only formulations registered to be applied with agricultural sprayers were considered.

The objective of the research was to find matches of plant protection products applied with agricultural sprayers, containing the same active substances and registered for protection of winter wheat against the selected pests in different formulations. To calculate the amount of an active substance per hectare it was estimated (following the methodology of Matyjaszczyk (2017)) that the products were applied according to the maximum recommended dosage.

\section{RESULTS}

During the research it was noted that the occurrence of products which contain identical active substances for winter wheat protection in different formulations was not uncommon. In the course of the research it became evident that several matches of products with different formulations are registered to control the selected pests in winter wheat. The details are presented in Table 1 (herbicides) and Table 2 (fungicides). It was found that among fungicidal active substances fulfilling the search criteria only one: tebuconazole was registered in different formulations. For the herbicides six cases fulfilling the search criteria were found: four active substances solo plus two combinations of two different active substances.

The results as regards the dose used per hectare are the following:

- All herbicides matching the search criteria were registered in two different formulations, the only fungicide was registered in three different formulations.

- For one active substance, namely herbicide metsulphuron methyl identical maximal dose was recommended, regardless of the trade names of the products and the formulation.

- For both herbicidal combinations of active substances different maximal doses were recommended in different formulations, however recommended dose of one active substance was higher, while of the second - lower. Since it is very difficult to compare quantitative use of different active substances, therefore in both cases it is difficult to draw any conclusions regarding the quantitative use of active substance per hectare.

- For two active substances, herbicide MCPA and fungicide tebuconazole the maximal recommended dose depended rather on the product, that on the formulation. In both cases majority of products on the market, regardless of the formulation were registered in identical dose: for MCPA $750 \mathrm{~g} / \mathrm{ha}$, while for tebuconazole $250 \mathrm{~g} / \mathrm{ha}$. However for MCPA one product was registered in significantly higher dose $900 \mathrm{~g} / \mathrm{ha}$ and for tebuconazole three products were registered in slightly higher dose $258 \mathrm{~g} / \mathrm{ha}$ and one in significantly higher dose $312,5 \mathrm{~g} / \mathrm{ha}$.

- For two active substances: herbicides tribenuron and fenoxaprop-P the formulation seems to influence the maximal dose of active substance recommended per hectare. In case of fenoxaprop-P the registered dose is higher in formulation $\mathrm{EW}$ than in formulation $\mathrm{EC}$ and the difference is below $10 \%$. For tribenuron results are not so clear because several different doses is registered 
under different trade names, however generally speaking the recommended dose was higher in formulation SG, than in formulation WG.

Table 1. Comparison of matches of herbicides containing the same active substance in different formulations registered for protection of winter wheat against Chenopodium album, registered in Poland in May 2017.

\begin{tabular}{|c|c|c|c|c|c|}
\hline $\begin{array}{c}\text { Active } \\
\text { substance }\end{array}$ & $\begin{array}{l}\text { Formulati } \\
\text { on* }\end{array}$ & Product trade name & Dose & $\begin{array}{l}\text { Content of } \\
\text { active } \\
\text { substance }\end{array}$ & $\begin{array}{l}\text { Total use } \\
\text { of active } \\
\text { Substance }\end{array}$ \\
\hline \multirow{4}{*}{ MCPA } & \multirow[b]{3}{*}{ SL } & Premier 300 SL & 3 1/ha & $300 \mathrm{~g} / 1$ & $900 \mathrm{~g} / \mathrm{ha}$ \\
\hline & & $\begin{array}{c}\text { Agritox } 500 \text { SL, Premier } 500 \\
\text { SL }\end{array}$ & $1,5 \mathrm{l} / \mathrm{ha}$ & $500 \mathrm{~g} / 1$ & $750 \mathrm{~g} / \mathrm{ha}$ \\
\hline & & $\begin{array}{c}\text { Agroxone Max } 750 \text { SL, } \\
\text { Ceridor MCPA } 750 \text { SL, } \\
\text { Chwastoc Professional } 750 \\
\text { SL, Dicoherb } 750 \text { SL, Premier } \\
\text { 750 SL }\end{array}$ & 1 l/ha & $750 \mathrm{~g} / 1$ & $750 \mathrm{~g} / \mathrm{ha}$ \\
\hline & $\mathrm{EC}$ & Chwastoc AS 600 EC & $1,251 / \mathrm{ha}$ & $600 \mathrm{~g} / 1$ & $750 \mathrm{~g} / \mathrm{ha}$ \\
\hline \multirow{2}{*}{$\begin{array}{c}2,4- \\
\text { D+dicamb } \\
\mathbf{a}\end{array}$} & $\mathrm{EC}$ & Aminopielik D Maxx 430 EC & $1,5 \mathrm{l} / \mathrm{ha}$ & $\begin{array}{c}376 \mathrm{~g} / 1+54 \\
\mathrm{~g} / 1\end{array}$ & $\begin{array}{c}564 \\
\mathrm{~g} / \mathrm{ha}+81 \\
\mathrm{~g} / \mathrm{ha}\end{array}$ \\
\hline & SL & $\begin{array}{c}\text { Aminopielik Super } 464 \text { SL, } \\
\text { Dicopur Top } 464 \text { SL, Tayson } \\
464 \text { SL }\end{array}$ & 1 1/ha & $\begin{array}{c}344 \mathrm{~g} / \mathrm{l}+120 \\
\mathrm{~g} / 1\end{array}$ & $\begin{array}{c}344 \\
\mathrm{~g} / \mathrm{ha}+120 \\
\mathrm{~g} / \mathrm{ha}\end{array}$ \\
\hline \multirow{3}{*}{$\begin{array}{l}\text { thifensulfu } \\
\text { ron- } \\
\text { methyl+me } \\
\text { tsulfuron- } \\
\text { methyl }\end{array}$} & WG & $\begin{array}{c}\text { Chenkar } 750 \text { WG, Ergon } 750 \\
\text { WG, Looma } 750 \text { WG, Vima- } \\
\text { Tifenmet }\end{array}$ & $75 \mathrm{~g} / \mathrm{ha}$ & $\begin{array}{c}682 \\
\mathrm{~g} / \mathrm{kg}+68 \\
\mathrm{~g} / \mathrm{kg}\end{array}$ & $\begin{array}{c}51,15 \\
\mathrm{~g} / \mathrm{ha}+5,1 \\
\mathrm{~g} / \mathrm{ha}\end{array}$ \\
\hline & \multirow{2}{*}{ SG } & Concert SX 44 SG & $150 \mathrm{~g} / \mathrm{ha}$ & $\begin{array}{c}400 \\
\mathrm{~g} / \mathrm{kg}+40 \\
\mathrm{~g} / \mathrm{kg}\end{array}$ & $\begin{array}{c}60 \mathrm{~g} / \mathrm{ha}+6 \\
\mathrm{~g} / \mathrm{ha}\end{array}$ \\
\hline & & Finish SX 40 SG & $75 \mathrm{~g} / \mathrm{ha}$ & $\begin{array}{c}333 \\
\mathrm{~g} / \mathrm{kg}+67 \\
\mathrm{~g} / \mathrm{kg} \\
\end{array}$ & $\begin{array}{c}24,97 \\
\mathrm{~g} / \mathrm{ha}+5,02 \\
\mathrm{~g} / \mathrm{ha} \\
\end{array}$ \\
\hline \multirow{2}{*}{$\begin{array}{c}\text { metsulfuro } \\
\text { n-methyl }\end{array}$} & WG & $\begin{array}{c}\text { Coma } 20 \text { WG, Finy } 200 \text { WG, } \\
\text { Pike } 20 \text { WG, Winnetou } 20 \\
\text { WG }\end{array}$ & $30 \mathrm{~g} / \mathrm{ha}$ & $200 \mathrm{~g} / \mathrm{kg}$ & $6 \mathrm{~g} / \mathrm{ha}$ \\
\hline & SG & $\begin{array}{c}\text { Galmet } 20 \text { SG, Primstar } 20 \\
\text { SG, Superherb } 20 \text { SG }\end{array}$ & $30 \mathrm{~g} / \mathrm{ha}$ & $200 \mathrm{~g} / \mathrm{kg}$ & $6 \mathrm{~g} / \mathrm{ha}$ \\
\hline \multirow{5}{*}{ tribenuron } & \multirow[b]{3}{*}{ WG } & Lumer $50 \mathrm{WG}$ & $30 \mathrm{~g} / \mathrm{ha}$ & $500 \mathrm{~g} / \mathrm{kg}$ & $15 \mathrm{~g} / \mathrm{ha}$ \\
\hline & & Cuckoo $750 \mathrm{WG}$ & $25 \mathrm{~g} / \mathrm{ha}$ & $750 \mathrm{~g} / \mathrm{kg}$ & $18,75 \mathrm{~g} / \mathrm{ha}$ \\
\hline & & $\begin{array}{c}\text { Helgran } 75 \text { WG, Naxel } 75 \\
\text { WG, Nuance } 75 \text { WG, Pleban } \\
75 \text { WG, Ranga } 75 \text { WG, Sabata } \\
75 \text { WG, Tribe } 75 \text { WG, Viking } \\
75 \text { WG }\end{array}$ & $20 \mathrm{~g} / \mathrm{ha}$ & $750 \mathrm{~g} / \mathrm{kg}$ & $15 \mathrm{~g} / \mathrm{ha}$ \\
\hline & \multirow[b]{2}{*}{ SG } & Granstar SX 50 SG & $35 \mathrm{~g} / \mathrm{ha}$ & $500 \mathrm{~g} / \mathrm{kg}$ & $17,5 \mathrm{~g} / \mathrm{ha}$ \\
\hline & & $\begin{array}{c}\text { Toraya } 50 \text { SG, Triben Super } \\
50 \text { SG, Trimax } 50 \text { SG, Tristar } \\
50 \text { SG }\end{array}$ & $40 \mathrm{~g} / \mathrm{ha}$ & $500 \mathrm{~g} / \mathrm{kg}$ & $20 \mathrm{~g} / \mathrm{ha}$ \\
\hline \multirow[t]{2}{*}{$\begin{array}{c}\text { fenoxaprop } \\
\text {-P }\end{array}$} & EW & $\begin{array}{c}\text { Fantom } 069 \text { EW, Foxtrot } 069 \\
\text { EW, Norton 069 EW, Puma } \\
\text { Uniwersal 069 EW, Pumex } \\
\text { 069 EW, Rumba 069 EW }\end{array}$ & 1,2 1/ha & $69 \mathrm{~g} / 1$ & $82,8 \mathrm{~g} / \mathrm{ha}$ \\
\hline & $\mathrm{EC}$ & $\begin{array}{c}\text { Fenoxinn } 110 \text { EC, Herbos } 110 \\
\text { EC, Monarchi } 110 \text { EC }\end{array}$ & 0,7 1/ha & $110 \mathrm{~g} / 1$ & $77 \mathrm{~g} / \mathrm{ha}$ \\
\hline
\end{tabular}

*A key to formulation codes: SL (soluble concentrate), EC (emulsifiable concentrate), WG (water dispersible granule), SG (water soluble granule), EW (emulsion, oil in water) 
Table 2. Comparison of matches of fungicides containing the same active substance in different formulations registered for protection of winter wheat against powdery mildew, registered in Poland in May 2017.

\begin{tabular}{|c|c|c|c|c|c|}
\hline $\begin{array}{c}\text { Active } \\
\text { substance }\end{array}$ & $\underset{*}{\text { Formulation }}$ & Trade names of products & Dose & $\begin{array}{l}\text { Content of } \\
\text { active } \\
\text { substance }\end{array}$ & $\begin{array}{c}\text { Total use } \\
\text { of active } \\
\text { substance }\end{array}$ \\
\hline \multirow{5}{*}{$\begin{array}{c}\text { tebuconazo } \\
\text { le }\end{array}$} & $\mathrm{EC}$ & Brasifun $250 \mathrm{EC}$, Mystic $250 \mathrm{EC}$ & 1 1/ha & $250 \mathrm{~g} / 1$ & $250 \mathrm{~g} / \mathrm{ha}$ \\
\hline & \multirow[t]{2}{*}{ EW } & $\begin{array}{c}\text { Clayton Tabloid EW, Darcos } 250 \\
\text { EW, Domnic } 250 \text { EW, Erasmus } 250 \\
\text { EW, Furtado } 250 \text { EW, Helicur } 250 \\
\text { EW, Kosa } 250 \text { EW, Orius Extra } 250 \\
\text { EW, Riza } 250 \text { EW, Sokolov } 250 \\
\text { EW, Sparta } 250 \text { EW, Syrius } 250 \\
\text { EW, Tarcza Łan } 250 \text { EW, Tebu } 250 \\
\text { EW, Tebusha } 250 \text { EW, Toledo } 250 \\
\text { EW, Trion } 250 \text { EW, Troja } 250 \text { EW, } \\
\text { Tyberius } 250 \text { EW }\end{array}$ & 1 1/ha & $250 \mathrm{~g} / \mathrm{l}$ & $250 \mathrm{~g} / \mathrm{ha}$ \\
\hline & & Tarcza Lan Extra 250 EW & $\begin{array}{l}1,25 \\
1 / \mathrm{ha}\end{array}$ & $250 \mathrm{~g} / \mathrm{l}$ & $312,5 \mathrm{~g} / \mathrm{ha}$ \\
\hline & \multirow[b]{2}{*}{$\mathrm{SC}$} & Ambrossio 500 SC, Venturo 500 SC & 0,5 1/ha & $500 \mathrm{~g} / 1$ & $250 \mathrm{~g} / \mathrm{ha}$ \\
\hline & & $\begin{array}{c}\text { Bounty } 430 \text { SC, Spekfree } 430 \text { SC, } \\
\text { Starpro } 430 \text { SC }\end{array}$ & 0,6 l/ha & $430 \mathrm{~g} / 1$ & $258 \mathrm{~g} / \mathrm{ha}$ \\
\hline
\end{tabular}

\section{CONCLUSION}

On the basis of the results, it is difficult to draw any definite conclusions regarding the influence of formulation on the dose of active substance used per hectare. The collected data show that in many cases for the same active substance and formulation different maximal doses were recommended to control the same pest in the same crop, it may however depend on the recommended growth stage of application, which was not considered. In some cases, use of a different formulation may be connected with the different amount of an active substance used per hectare. However, the results strongly differed depending on the analyzed active substances. Probably more cases should be examined to determine whether there are any discernible patterns.

\section{REFERENCES}

Bereś P. K. (2016). Efficacy of spinosad and Bacillus thuringiensis var. kurstaki in biological control of the european corn borer on sweet corn. Acta Scientiarum Polonorum-Hortorum Cultus, Volume: 15 (issue: 6), pages: 19-35.

DIRECTIVE 2009/128/EC OF THE EUROPEAN PARLIAMENT AND OF THE COUNCIL of 21 October 2009 establishing a framework for Community action to achieve the sustainable use of pesticides, Official Journal of the European Union.

Doruchowski G., Świechowski W., Masny S., Maciesiak A., Tartanus M., Bryk H., Hołownicki R. (2017). Low-drift nozzles vs. standard nozzles for pesticide application in the biological efficacy trials of pesticides in apple pest and disease control. Science of The Total Environment, Volume: 575, pages: 1239-1246.

Hoesel W., Tiefenbacher A., König N., Dorn V. M., Hagenguth J.F., Prah U., Widhalm T., Wiklicky V., Koller R., Bonkowski M., Lagerlöf J., Ratzenböck A., Zaller J.G. (2017). Single and Combined Effects of Pesticide Seed Dressings and Herbicides on Earthworms, Soil Microorganisms, and Litter Decomposition. Frontiers in Plant Science, Volume 8, Article: 215. 
Hurej M., Kucharczyk H., Twardowski J.P., Kotecki A. (2017). Thrips (Thysanoptera) associated with two genetically modified types of linseed (Linum usitatissimum L.). Journal of Plant Diseases and Protection, Volume: 124 (issue: 1), Pages: 81-91

Jankowska M., Kaczyński P., Hrynko I., Łozowicka B. (2016). Dissipation of six fungicides in greenhouse-grown tomatoes with processing and health risk. Environmental Science and Pollution Research, Volume: 23 (Issue: 12), pages: 11885-11900.

Kazimierczak R., Siłakiewicz A., Hallmann E., Srednicka-Tober D., Rembiałkowska E. (2016). Chemical Composition of Selected Beetroot Juices in Relation to Beetroot Production System and Processing Technology. Notulae Botanicae Horti Agrobotanici Cluj-Napoca, Volume: 44 (issue: 2), pages: 491-498.

Matyjaszczyk E. (2011). Selected aspects of plant protection in Poland, five years on from EU accession. Outlook on Agriculture vol 40, (Issue 2) pages 119-123.

Matyjaszczyk E. (2017). Comparison between seed and foliar treatment as a tool in integrated pest management. J. Agric. Food Chem. DOI: 10.1021/acs.jafc.7b01095.

Melski K., Kubera H., Głuszewski W., Zimek Z. (2011). Effect of ionizing radiation on the properties of PLA packaging materials. Nukleonika, Volume: 56 (issue: 1), pages: 65-69.

Parafiniuk S., Milanowski M., Subr A.K. (2015). The influence of the water quality on the droplet spectrum produced by agricultural nozzles. Agriculture and Agricultural Science Procedia, Volume: 7 pages: $203-208$.

Pikuła, D., Rutkowska, A. (2014). Effect of leguminous crop and fertilization on soil organic carbon in 30-years field experiment. Plant, Soil and Environment, Volume: 60 (issue: 11), pages: 507-511.

Szpyrka E., Matyaszek A., Słowik-Borowiec M. (2017). Dissipation of chlorantraniliprole, chlorpyrifosmethyl and indoxacarb-insecticides used to control codling moth (Cydia pomonella L.) and leafrollers (Tortricidae) in apples for production of baby food. Environmental Science and Pollution Research, Volume: 24 (issue: 13), pages: 12128-12135.

Zarzyńska K., Boguszewska-Mańkowska D., Nosalewicz A. (2017). Differences in size and architecture of the potato cultivars root system and their tolerance to drought stress. Plant, Soil and Environment, Volume: 63 (issue: 4), pages: 159-164. 